\title{
Role of Translator as a Gap Filler in Communication with Reference to Françoise Balogun
}

\author{
ZAKI, Muhammad Zayyanu \\ muhammad.zayyanu@udusok.edu.ng \\ Department of French, Faculty of Arts, Usmanu Danfodiyo University, Sokoto \\ https://orcid.org/0000-0003-3785-2488 \\ SAJO, Muhammad Aliyu, Ph.D \\ muhammadsajo2005@yahoo.com \\ Department of English and Literary Studies, Faculty of Arts, Usmanu Danfodiyo University, Sokoto \\ John Ogboji \\ Obgojijoh2014@gmail.com \\ Department of General Studies, Benue State Polytechnic, Ugbokolo
}

DOI: 10.47760/cognizance.2021.v01i11.002

\begin{abstract}
Translation of messages between two languages has been very challenging among translators. Translations have led to the filling of gaps in communication barriers so that equivalence and accuracy are achieved in the process of transfer of messages from one language to another. This paper aims to examine the role of a translator in filling the communication gap between the Source Language (SL) and the Target Language (TL). These gaps are known as translation problems or difficulties as a means of solving them. We apply the interpretative and comparative approaches of translation. This is achieved through the extract of texts from the English and French versions of our corpus. The main objectives of the paper are i) to examine some concepts in translation ii) to identify some gaps in translation, and iii) to determine the approach that fits better in translating discourse messages with varied contexts. Among the findings of the study are instances of gap filling in communication as no two languages see a concept in the same way that includes i) set and series, ii) cultural words, and iii) neologism. The study concludes that equivalent is the key to achieving successful translation across cultures.
\end{abstract}

Keywords: Equivalence, gap filler, communication, culture, Source Language (SL), Target Language (TL) 
cognizancejournal.com

ZAKI, Muhammad Zayyanu et al, Cognizance Journal of Multidisciplinary Studies, Vol.1, Issue.11, November 2021, pg. 9-21 (An Open Accessible, Multidisciplinary, Fully Refereed and Peer Reviewed Journal)

ISSN: 0976-7797

\section{Introduction}

Language and translation go hand in hand because language is a tool used to manipulate knowledge and skills through the translation processes. Language is credibly complex in communication. Thus, a translator makes lots of decisions and transformations given the available text. There is no identical languages in terms of similarity, as each language sees a concept differently. In language, pragmatics deals with meaning where our main concern is coherence. According to Baker (2018) pragmatics is "the study of meaning, not as generated by the linguistic system but as conveyed and manipulated by participants in a communicative situation". The translator considers the context of source language culture in transforming the message to a target language culture. A translator faces difficulties in cross-cultural communication through the process of gap-filling in order to make sense out of it. Therefore, the translator is part and parcel of all worldwide localisation and glocalization processes, Pym (19). Translation is therefore just a by-product of globalisation, but an integral part of it.

The pedagogical usefulness of translation as a complex cross-linguistic and crosscultural activity is its strong pragmatic component which makes translation potentially beneficial for language learners. This cross-cultural and cross-linguistic activity is achieved by a translator in the translation process. The expansion of digital industries centred on elearning and other education forms have spread like mialfire over the Internet in many different languages. According to (House 152) translation is now "more often seen as an omnipresent general interpretative activity that plays an important role in realizing pragmatic meaning within and across languages, and translation is frequently regarded as a natural pragmatic process in acquiring a foreign language". One can only understand a foreign language through the translation of that language to discover its culture, ideas, or thoughts that were hidden because of language. The role of a translator in language cannot be overemphasized in this study, as we explore some gaps in the translation and translator process.

Besides, a gap in translation occurs as French culture has its concepts and these differ from those of the English language; this is where a translator comes in. The translator identifies the differences in terms of grammar, structures and culture which are part of the function or role of the translator in this research. The gap in translation refers to some correspondences between the source language text and target language text of culturally 
specific words. The boundary that the translators bridges is caused by the translation difficulties or gaps. Therefore, the translator is actively creating something new in the TL, and culture which will maintain an equivalent relationship between the source culture and the target culture.

So, the translator tends to fill the gap by reducing or eliminating the differences between the two cultures of the languages by providing correspondence and/or equivalence. As (Ketkar 16) further explains that "the traditional discussion of the problems of literary translation considers finding equivalents not just for lexis, syntax or concept but also for features like style, genre, figurative language, historical stylistic dimensions, polyvalence, connotations as well as denotations, cultural items and culture-specific concepts and values". Those are some of the issues in the translation process and functions of a translator in translation. According to (Zona 10) "translation could not have developed without culture. Literature, science and philosophy influence translators' conceptualisations". On the other hand, "culture could not have developed without translation, since translations enrich nations with the cultural values of other nations". The conceptualisations of translators help in outing together ideologies across culture and language. This is where the translator fills the gap and a question of getting the right translator for a task rises.

Thus, translators with good working knowledge of colloquialisms, dialect and slang in the native language, who can get across their meaning and help to come up with appropriate equivalents, do not jar with the reader and most importantly, do not date. Translators provide the reader with a glossary that can serve the purpose of explaining more obscure geographical and cultural references. As (Vinay and Darbelnet 31) further add that "because of structural or metalinguistic differences, certain stylistic effects cannot be transposed into TL without upsetting the syntactic order or even the lexis". Thus, the translator manages to transform the message as appropriately as possible using wording as was in the original.

\section{Some Concepts of Translation in Discourse}

The translation is viewed in different contexts and different situations by scholars in theory and practice. The translation is a "constant evaluative process: it encompasses the checking of possible TT equivalents against the ST and each other in a process of refinement that leads to the selection of a single equivalent", Munday (155). Finding equivalence in 
translation plays a vital role across languages. The fact is that "holding this world together, or keeping it apart, has linguistic industries. At the boundaries of languages are the translators mediators of cultures, enablers, but also gatekeepers", Tonkin, et al., (8). The authors state that "the task of the translator, conceived precisely as a mediator between (or among) cultures, concentrates most immediately on the work of making a text in one language available in another", Tonkin, et al., (123). Also, Munday, (38) further explains that translation is "clearly an example of a text that is produced for a new communicative purpose, or at least that is normally directed at an audience different from that envisaged by the source". A translator is a mediator between languages, as s/he produces another text in another language using knowledge and experience in searching for the right equivalence. Translation is seen as "so efficient that what is uttered in any language can be practically accessed in any other language", Tonkin, et al., (75-76). As Tokin, et al., explain that "translation is inescapably a process in which the foreign is domesticated, the strange rendered familiar and, in the process, largely effaced", Tonkin, (114). They further explained that "translation is imagined to be a process of decoding and recoding", Tonkin, (115). All the above views by different scholars show that the translators mediates between and across languages in finding the right correspondence and/or equivalence to make the translation as the original.

Researchers consider written expression in this case as text. Tonkin, et al., (59) say that "the interpreter is much like any other listener, making sense of the discourse as it is expressed through time". In other words Fairclough, (17) opines that "discourse is a particular way of representing some part of the (physical, social, psychological) world". The author states that "discourse is partly social relations", (Fairclough 25). It is further explained that "'discourse' is used here in two senses: abstractly as a noun, meaning language and other types of semiosis as elements of social life; more concretely, [...], meaning particular ways of representing part of the world", (Fairclough 26). It can be said that meaning plays a vital role in translation, as everything can be transformed across cultures and languages except, meaning. We conclude that the translator cannot temper with meaning as it is the key in the translation process. 


\section{Overview on Gap and Filling the Gaps between Languages}

A gap is a difference between texts or contextual knowledge in a given language and its representation in another language using culture, experience and terminologies in translation. It is "an opening that implies a breach", in our case study between communication and between languages. It is also an unfilled space between texts or languages. There is a perfect similarity between languages. This is a linguistic phenomenon that brings about many differences in various languages among which are cultural words, lexical gap, semantic gap and neologism. According to (Hatim 24), "translation is a particularly complex process, a situation that may be exacerbated by the difficulty inherent in the languages and cultures involved exhibiting a significant intertemporal gap". There is frequently the problem of the mediating language and culture of the translator possibly exerting an influence on how the target text takes shape. More serious perhaps is the problem of the translated work losing its original contextual significance (e.g. the genre in which the ST is written becoming defunct in the TL at the time of translating).

So, the gap the translator fills is obtained by marking the boundary between the languages (French and English) through the underlying principles of a basic conceptual structure of the process in which an original work is created and of the subsequent procedure involved in the creation of a translation that works. The translation is the act of transmitting a message from one language to another as supported by (Levy 23), that "translators decode the message contained in the text of the original author and reformulate (encode) it into their language". Translators play a vital role as a bilingual or multilingual gap fillers in communication.

Besides, the message contained in the translated text is then decoded by the reader of the translation. The role of a translator is to put his/her experiences, wisdom and skills of translation to occupy the gap and to consider the following in the process of transforming the message between the languages: a) finding equivalence, have confidence in the task and make difficult decisions, b) using knowledge, c) applying techniques, d) understanding at least two languages, e) considering mistakes (minor mistakes) as in human errors, f) weighing the quality of a text and g) identifying untranslatable words and culture-specific references. Also, as stated by De Jong, (28) that, the "differences between cultures and languages may lead to grave, indeed tragic, misunderstanding; it is, therefore, imperative that

${ }^{1}$ Wikitionary, 2020 accessed $3^{\text {rd }}$ November, 2020. 
cognizancejournal.com

ZAKI, Muhammad Zayyanu et al, Cognizance Journal of Multidisciplinary Studies, Vol.1, Issue.11, November 2021, pg. 9-21 (An Open Accessible, Multidisciplinary, Fully Refereed and Peer Reviewed Journal)

those persons who serve as linguistic intermediaries be not only proficient in their working languages, but also cognizant of how linguistic forms are culturally dependent for effective communication". The understanding of the cultural background of languages is what makes an interpretation or translation complete. Anything one says can be said in another form or better than that. Translation is not necessarily relying on the original text while translating because, a message can be put across in different forms. The key in translation is the meaning.

Various researches were conducted on gap-filling. They include Wu, Sag, (2008), Atkison, (2017) which deals with cultural gaps and their translation. They compare the different cultural connotations of expressions in English and Chinese and analyses certain cases which are often reflected in the translation process: cultural background; nonequivalence; extension and intension; derivation. Then some methods are put in place in this direction to solve the problems. Zlateva, (ND) discussed linguistic aspects, structures and features in English and Russian languages, giving examples of expanding functional equivalents to the point of gap-filler and even substitutes for verbal expressions. Sag (2008) observed grammatical and syntactic constructs in English grammar. The author adopted the Chomskyan universal and transformational grammar and applied a construction-based approach to grammar description.

Atkison's work (2017) Communicating Across Cultures: The Role of Language Interpreters uses Edward Hall's Theory which helps to decipher the culture of an individual. The researcher uses interviews as a method of collecting data. The researcher found out the following result: cultural barriers that exist while interpreting, challenges in areas they are not knowlegeable in, and the interpreters felt like they had to prepare ahead of time before the translation. Half of the interpreters interviewed mentioned that they did not have any cultural restrictions within their culture. Due to differences in language, some words or phrases may not be interpretable.

To the best of researchers' knowledge, this research is considering the work of a translator, Françoise Balogun as a reference in filling the gap. He translated series of literary works that include La Brousse ardent from the Burning Grass of Cyprian Ekwensi. The Burning Grass is a literary work that explains the aspects of Fulani and their culture. 


\section{Methodology and method of Collecting Data}

As meaning is the priority in translation, this study employs the interpretative and comparative methods as well as a pragmatic approaches to examine and evaluate the meaning considered by the translator in filling the gap of communication. Scholarly works covering textbooks and e-resources are used as reference materials from which data are extracted. Two texts are selected as the corpus, they are: The Burning Grass (1962) by Cyprian Ekwensi and la Brousse ardente translated version into French by Françoise Balogun.

\section{Instances of Gap filling in Communication}

In this part, the researchers identify, describe and infer to the instances cited in the translated work(s) that a translator fills the gap by forming a newly translated text from the English language to the French. Some instances are extracted from the translation of Fançoise Balogun's Burning Grass to French as la Brousse ardente. The gap filled by a translator must find a text-specific solution to achieve acceptance in the target text language; this may be terminology where gaps are understood. These gaps are termed translation problems or difficulties, they include cultural words, lexical gap, semantic gap, sets and series, conceptual terms, words as myth, or neologism as used in Componential Analysis. These are identified on the level of meaning and in translation, the study deals with meaning. The researchers selected issues of culture from the above-mentioned and cited instances below:

\section{Sets and series}

The following are terminologies used to distinguish the meaning of SL cultural sets or series when their TL equivalents have widely different functional components.

\section{Extract 1 -}

\begin{tabular}{|l|l|l|}
\hline \multicolumn{1}{|c|}{ Original Text } & \multicolumn{1}{|c|}{ Translated text } & \multicolumn{1}{c|}{ Gap filled } \\
\hline$\ldots$ it is time for the & $\ldots$ c'est, pour les & The translator used some \\
herdsmen to be moving & bergers, le moment & terminologies \\
the cattle southwards to & d'emmener le bétail \\
the bank of the great & differentiate cultural sets \\
river. p.1. & vers les rives du grand & in the original text with \\
& fleuve, au sud. p. 9. & $\begin{array}{l}\text { their equivalent translated } \\
\text { text. }\end{array}$ \\
\hline
\end{tabular}

\section{Observation:}

In reality, the Fulani move from one place to another in search of food and water for their animals, usually where there is grass and river or flowing water. They leave their 
settlement (rugga) in some cases with their family to the South in search of food for their cattle. Traditionally, they stay for a year moving and following the availability of water and pasture here and there and return to (mashekare) during the rainy season in the North. From the text, the translator starts with the movement of Fulani to the South. He shows that their business is growing animals, selling their products and the animals (usually cattle and sheep).

\section{Cultural words}

Words describe the culture and society using them. Translation is a difficult task considering the cultural words and differences a translator encounters during translation. Some words are used to express a given situation in one language may not exist in another. The audience is unlikely to understand some cultural aspects in the SL as this can be achieved through filling the gap by the translator through accompanying it with acceptable translation, transference and finding cultural equivalent that shows the relevance of the cultural words in the text. An instance is selling cheese in the original text which will be difficult to compare with the French's selling cakes and pastries. The translator needs to make adjustments by filling the gap by considering the cultural context of the original text to maintain the same in the translated text.

\section{Extract 2 - Cultural belief}

\begin{tabular}{|c|c|c|}
\hline Original Text & Translated text & Gap filled \\
\hline $\begin{array}{l}\text {... she could milk the } \\
\text { cows, separate butter } \\
\text { and cheese from the } \\
\text { milk, ferment the milk } \\
\text { and cook. ... to hawk } \\
\text { the sour milk ... p.5. }\end{array}$ & $\begin{array}{l}\text {... elle savait traire les } \\
\text { vaches, préparer le } \\
\text { beurre et le fromage, } \\
\text { faire fermenter le lait et } \\
\text { cuisiner ... vendre le } \\
\text { lait caillé ... p. } 15 .\end{array}$ & $\begin{array}{l}\text { The translation was } \\
\text { achieved by finding } \\
\text { acceptable cultural } \\
\text { equivalents in the text. } \\
\text { Here, some adjustments } \\
\text { were made by the } \\
\text { translator through } \\
\text { considering the culture of } \\
\text { the original text (selling } \\
\text { cheese locally by the } \\
\text { Fulani women) in } \\
\text { comparison with the } \\
\text { target culture (selling } \\
\text { cheese in France). }\end{array}$ \\
\hline
\end{tabular}

\section{Observation:}

The translator protects the meaning of the original text where he shows the role of Fulani as represented in the translated text - Brousse ardente. The female Fulani assist their husbands in managing the affairs of the animals, they treat milk and products of milk that consist of 
milk itself, butter and cheese which are sold at the end. The milk is a source of revenue where women milk the cows and sell them at the market. They use the income to buy food for the animals to have the energy to return to the bush. The translator shows the use of coinage as a translation technique with the modification of the word (our) in English with the word (le) in French.

Extract 3 - Charm

\begin{tabular}{|c|c|c|}
\hline Original Text & Translated text & Gap filled \\
\hline $\begin{array}{l}\text { If only Mai Sunsaye } \\
\text { had at that moment } \\
\text { remembered the } \\
\text { Sokugo, that charm of } \\
\text { the Fulani cattlemen; a } \\
\text { magic that turned } \\
\text { studious men into } \\
\text { wanderers, that led } \\
\text { husbands to desert their } \\
\text { wives, Chiefs their } \\
\text { people and sane men } \\
\text { their reason, Sunsaye } \\
\text { would have refused to } \\
\text { pursue the dove any } \\
\text { further. p. } 10 \text {. }\end{array}$ & $\begin{array}{l}\text { Si seulement Mai } \\
\text { Sunsaye s'était alors } \\
\text { souvenu du Sokugo, ce } \\
\text { charme des bergers } \\
\text { Fulani, un charme qui } \\
\text { rendait vagabonds les } \\
\text { hommes studieux, qui } \\
\text { poussait les maris à } \\
\text { abandonner leur } \\
\text { femme, les chefs leur } \\
\text { peuple, les hommes } \\
\text { sains leur raison, } \\
\text { Sunsaye aurait refusé } \\
\text { de poursuivre le pigeon } \\
\text { plus loin. p. } 23 .\end{array}$ & $\begin{array}{l}\text { Cultural shift assists the } \\
\text { translator, as the cultural } \\
\text { beliefs in the two texts } \\
\text { will be difficult to } \\
\text { maintain. The Fulani so } \\
\text { much believe in charm to } \\
\text { protect themselves and } \\
\text { their animals from savage } \\
\text { animals and wilderness. } \\
\text { Here, there is a kind of } \\
\text { blending of the culture to } \\
\text { bring out an acceptable } \\
\text { translation. }\end{array}$ \\
\hline
\end{tabular}

\section{Observation:}

The Fulani believe in charm, that is for one to have extraordinary power for protection. The author portrays the use of Sokugo in the text, in other words (Oriwima) or (Odenama) that is used in the translation. It is the charm that causes the hero (Mai Sunsaye) in the text to flee and leave behind everything that he owns including his family without his consent, through following a pigeon. It is a kind of charm used by Fulani for protection against enemies and wandering. These are beliefs in Fulani culture that may not be found in French culture.

\section{Neologism}

This is a situation where words are coined or newly created given procedures that are not available in the TL. This is where a translator "fills gaps in a language's resources for handling human thoughts" (Newmark 122). Coinage is a technique used by translators to fill the terminological gaps opened by the "intercultural and interlinguistic movement of knowledge, following in SL and culture or by the transfer of material", (Rogers 111). 
Translation deals with creativity, as the translator considers the general meaning of the text before transforming it to the culture of the target language. The process of searching for the cultural equivalence of a word into another language is certainly creative. The corpus for the study was extracted from examples from the two texts as in extracts 4 and 5 below:

\section{Extract 4 - Sharro}

Sharr: it is a Fulani term used in the original text and absorbed in the translated text in French. This terminology is neither available in English nor French languages as it is a cultural term used amongst the Fulani of the Western part of Africa. It is a cultural activity engaged among youth to show their courage, endurance and perseverance which impress a young Fulani lady to marry one. This can be translated by finding possible equivalence in the culture of the target language.

\begin{tabular}{|c|c|c|}
\hline Original Text & Translated text & Gap filled \\
\hline $\begin{array}{l}\text { A Fulani youth who } \\
\text { had not taken a } \\
\text { flogging at the } \\
\text { sharro would never } \\
\text { find a maiden to } \\
\text { marry him. p. } 65 \text {. }\end{array}$ & $\begin{array}{l}\text { Un jeune Fulani qui } \\
\text { n'a pas été fouetté à } \\
\text { sharro ne trouve pas de } \\
\text { jeune fille à épouser. p. } \\
97 .\end{array}$ & $\begin{array}{l}\text { The Sharro is the courage } \\
\text { in Fulani culture which can } \\
\text { only be portrayed using the } \\
\text { French language for native } \\
\text { speakers to understand. } \\
\text { This is assumed } \\
\text { equivalent, as it is not } \\
\text { existing in the French } \\
\text { culture. }\end{array}$ \\
\hline
\end{tabular}

\section{Observation:}

The translator maintains the Fulani culture, as he observes in the text that Sharro plays a vital role in Fulani's socio-cultural norms in portraying a man's courage. Neologism is applied in translation but, is more frequent in scientific and technical translations due to scientific inventions and terminologies.

\section{Extract 5- Baduhu (the equivalent of Black magic)}

It may be an equivalent of black magic in the European context but it is a very powerful charm used in the Fulani's world. As culture is a vast concept, the translator tries to translate and maintain the term in the linguistic culture of the source language to the target language culture. The translator puts into consideration the fact that culture is a vital element in dynamic societies.

\begin{tabular}{|r|c|c|}
\hline Original Text & Translated text & Gap filled \\
\hline From his pocket he & De sa poche, il sortit un & Culture is dynamic, as the \\
\hline
\end{tabular}




\begin{tabular}{|l|l|l|}
\hline drew a talisman of & talisman fait d'une peau & translator tries his possible \\
black catskin and & de chat noir et l'agita. & best to fill the gap \\
waved it. This was & C'était le baduhu dans & between the two cultures. \\
baduhu, known & toute la savane pour & \\
through the savannah & donner l'obscurité. p. 74 & \\
lands as the Giver of & & \\
Darkness. p.49. & & \\
\hline
\end{tabular}

\section{Observation:}

The translator considers the cultural terms such as charm, cattle and Fulani using procedures of translation to maintain the meaning of source language in the target language. It shows us that the Fulani consider charm as a form of protection to them and their animals. Currently, in West African countries like Nigeria, the Fulani use sophisticated weapons like AK47, AK49, grenades to protect their cows, territories against different attacks.

This is where the translator is left with searching for equivalence at the same time innovating the new situation from SL to TL through the use of the above-mentioned strategies combining with the pragmatic meaning.

\section{Research Findings}

Translators and interpreters are facing difficulties to cope with the terminological problems in their practical life to take care of the gap between languages and across cultures. This enables them to play a double role as a translator and also as terminologist while confronting new terms in the source language text or speech. Translators are central to filling the gap of communication that involves individuals who may not speak one language or the other. They contextualise the references for the reader on how best to approximate that experience to the reader. There are translation inadequacies because, translators face difficulties in connotative and denotative meaning differences and lexical gaps across languages which may be termed as omission or translation of different parts of speech.

\section{Conclusion}

The study has brought out some of the key terms relating to translation in communication. The concept and process of the translation where brought out in relation to communication. Some definitions of translation in discourse and communication were reviewed and how theorists and researchers in the fields that include gap filling, its kinds and 
cognizancejournal.com

ZAKI, Muhammad Zayyanu et al, Cognizance Journal of Multidisciplinary Studies, Vol.1, Issue.11, November 2021, pg. 9-21

(An Open Accessible, Multidisciplinary, Fully Refereed and Peer Reviewed Journal)

ISSN: 0976-7797

the main role of the translators in filling the gap between languages and cross-cultures are explored and manipulated during the research.

Also, examples are taken from the two versions: English as The Burning Grass by Cyprian Ekwensi and the French as la Brousse ardente translated by Françoise Balogun. These served as our corpus in analyzing and comparing the gap filled by a translator in communication. It was noted that the use of creativity assists translators in transforming messages into cross-cultural communication situations and solving problems by searching for correspondence and/or equivalence and the use of the right words.

In addition, translational gaps were raised are issues translators face due to a lack of lexical unit or lexical gap in another language to express the same meaning or its equivalence. These translation problems are solved by translators, and they are referred to as gaps. Translators are facing challenges in selecting suitable equivalents between languages. This may be as a result of advancement in globalization, International business, mass media and technology. The lexical gaps in translation are a result of different factors such as lack of comprehension of lexicalization of the same concepts in another language which lead to translation problems and difficulties. Another is the semantic gap that is characterized by the difference between concept described by different linguistic representations in another language.

\section{Cited/Consulted Works}

[1]. Atkison, M., 'Communicating Across Cultures: The Role of Language Interpreters'. Dis. The College at Brockport - State University of New York. 2017.

[2]. Baker. M., In other words: A coursebook on translation Third Edition. London: Routledge, 2018.

[3]. Ekwensi, C., Burning Grass: A story of the Fulani of Northern Nigeria. African Writers Series. Ibadan : Heinemann, 1962.

[4]. Ekwensi, C., La Brousse ardente: Histoire Fulani du Nord du Nigeria. Trans. Balogun, F. Paris : Présence Africaine, 1962.

[5]. Fairclough, N., Analysing Discourse - Textual Analysis for Social Research. London: Routledge - Taylor and Francis Group e-Library, 2003.

[6]. Hatim, B., Teaching and Researching Translation. Second edition. London: Routledge Francis and Taylor, 2013.

[7]. Munday, J., Evaluation in Translation - Critical Points of Translator Decision - Making. London: Routledge - Taylor and Francis, 2012.

[8]. Newmark, P., A Textbook of Translation. London: Longman, Pearson Education Press, 1988.

[9]. Nwanjoku, A., et al., 'Achieving Correspondence and/or Equivalence in Translation, An Evaluation of the Translation Ekwensi's Burning Grass into French as La Brousse ardente by 
Françoise Balogun'. Quest Journals - Journal of Research in Humanities and Social Science. Vol. 9, Issue 5, (2021) pages 50-55 Online: www.questjournals.org.

[10].Pym, A. Moving Text: Localization, Translation and Distribution. Philadelphia: John Benjamin Publication, 2004.

[11].Rogers, M. Terminology and Text: Closing the Gaps. Specialized Translation. Language and Linguistics Collection. London: Palgrave, 2015.

[12].Sag, I. V., English Filler-Gap Constructions. Stanford University. April 4, (2008).

[13].Tonkin, H, et al. Translator as a Mediator of Cultures. Philadelphia: John Benjamin Publication, 2010.

[14].Vinay, J. et Darbelnet, J., Comparative Stylistics of French and English: A Methodology of Translation. Trans. Juan, C., et al., Philadelphia: John Benjamin Publication, 1995.

[15].Vinay, J. et Darbelnet, J., Stylistique comparée du français et de l'anglais. Paris: Dédier, 1966.

[16].Wu, J., 'The Analysis of Cultural Gaps in Translation and Solutions'. CCSENET Journal. Vol. 1, No. 2, (2008) 22 -229

[17].Zona, R., Theory of Translation: English and Russian. $3^{\text {rd }}$ Edition. Beijin: Far Eastern University Press, 2008.

[18].Zlateva, P., Translation as a tool in Linguistic Analysis. University of Leeds, (ND). 